\title{
The Evolution of a State
}




\section{The Evolution of a State or}

\section{BY NOAH SMITHWICK}

Compiled by His Daughter

Nanna Smithwick Donaldson

Foreword by L. Tuffly Ellis

Illustrations by Charles Shaw

Barker Texas History Center Series, No. 5

UNIVERSITY OF TEXAS PRESS, AUSTIN 


\section{Recollections of Old Texas Days}
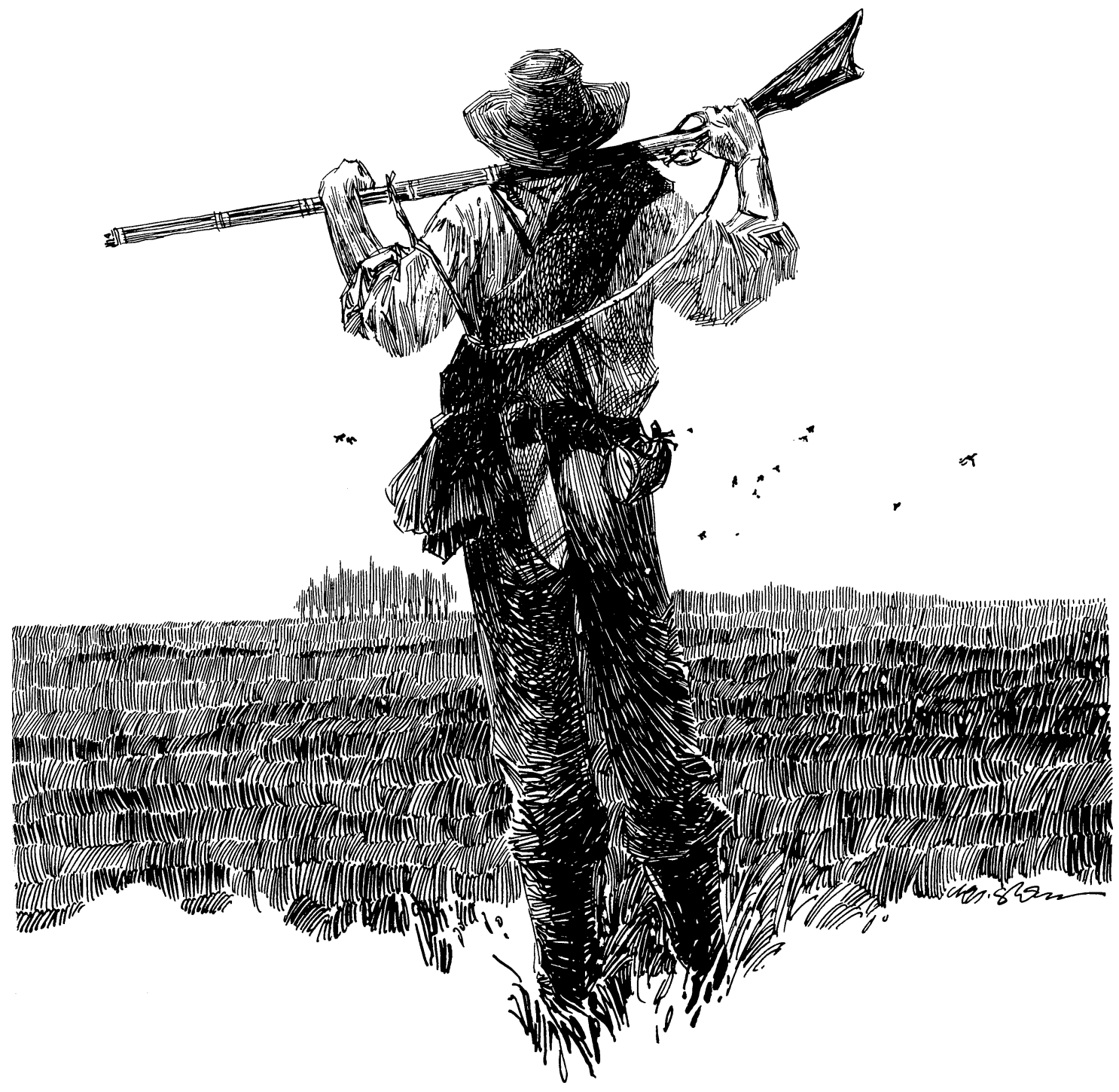
Copyright I 900 by H. P. N. Gammel

Copyright (C) 1983 by the University of Texas Press

All rights reserved

Printed in the United States of America

Eighth University of Texas Press paperback printing, 2009

Requests for permission to reproduce material from this work should be sent to:

Permissions

University of Texas Press

P.O. Box 7819

Austin, TX 78713-7819

www.utexas.edu/utpress/about/bpermission.html

@ The paper used in this book meets the minimum requirements of ANSI/NISO Z39.48-I992 (RI997) (Permanence of Paper).

ISBN 978-0-292-72045-9 (pbk.) 